\title{
Evaluation of genotoxic and cytotoxic effects of hydroalcoholic extract of Euphorbia tirucalli (Euphorbiaceae) in cell cultures of human leukocytes
}

\author{
MICHEL M. MACHADO ${ }^{1}$, LUIS F.S. DE OLIVEIRA', LUISA ZURAVSKI ${ }^{1}$, RAUL O. DE \\ SOUZA ${ }^{1}$, PAULA FISCHER ${ }^{1}$, JONATHALINE A. DUARTE ${ }^{1}$, MANOELLY O. ROCHA ${ }^{1}$, \\ CAMILA M. GÜEZ1, ALINE A. BOLIGON² and MARGARETH L. ATHAYDE ${ }^{2}$ \\ ${ }^{1}$ Programa de Pós-Graduação em Ciências Farmacêuticas, Universidade Federal \\ do Pampa, BR 472, Km 592, 97500-970 Uruguaiana, RS, Brasil \\ ${ }^{2}$ Programa de Pós-Graduação em Ciências Farmacêuticas, Departamento de Farmácia Industrial, Universidade \\ Federal de Santa Maria, Avenida Roraima, 1000, Campus Camobi, 97105-900 Santa Maria, RS, Brasil
}

Manuscript received on February 14, 2014; accepted for publication on July 13, 2015

\begin{abstract}
Euphorbia tirucalli (L.), commonly known as aveloz, has been indiscriminately used in popular medicine to treat various illnesses. However, some components can have devastating consequences. Injury to a cell's genetic material can cause mutations, cancer, and cell death. Our main goal in this work was to evaluate the genotoxic and cytotoxic effects of $E$. tirucalli extract on human leukocytes. For this purpose, we performed a phytochemical analysis to evaluate the plant's components. In the second step, we treated cultured human leukocytes with different concentrations of the dry extract of the plant and then evaluated the oxidative and genotoxic profiles of these leukocytes. We found that at $1 \%$ and $10 \%$ concentrations, the aveloz extract acted as a genotoxic agent that could damage DNA and increase oxidative damage. We conclude that despite its popular use, aveloz can act as a genotoxic agent, especially when it contains phorbol ester. Aveloz's indiscriminate use might actually promote tumors and therefore carry a considerable genetic risk for its users.
\end{abstract}

Key words: Aveloz, Euphorbia tirucalli, leukocytes, genotoxic, cytotoxic.

\section{INTRODUCTION}

Approximately three-quarters of the world's population use plants as a source for substances with pharmacological and therapeutic properties primarily to treat diseases and maintain health. Therefore, a significant number of people directly depend on alternative medicine as a primary form of treatment for chronic diseases (Mengue et al.

Correspondence to: Michel Mansur Machado

E-mail: michelmachado@unipampa.edu.br
2001, Ritter et al. 2002, Mendonça Filho and Menezes 2003, Pereira et al. 2004, Vendruscolo et al. 2005, Carlini 2003, Agra et al. 2007, Biavatti et al. 2007).

Euphorbia tirucalli (L.), popularly known as pencil tree, dog's stick, or aveloz, is a plant indigenous to Africa but well adapted in Brazil that has been indiscriminately used in popular medicine to treat various illnesses and conditions, including snake bites, asthma, and muscle spasms (Valadares et al. 2006). Moreover, aveloz has been reported 
to have antiviral and antimicrobial properties (Jurberg et al. 1985), as well as molluscicidal and larvicidal properties (Yadav et al. 2002). Aveloz also has been used as a home treatment for various types of cancer (Madureira et al. 2004). This plant presents a wide range of bioactive constituents, including quercetin, rutin, gallic acid, caffeic acid, taraxasterol, tirucallol, 12-O-tetradecanoylphorbol13-acetate (TPA), ingenane, togliane, and diterpenic acid derivatives (Fürstenberger and Hecker 1986). Interestingly, some reports have indicated that the pharmacological properties of the crude plant extracts can be lost after specific compounds are isolated; this indicates that at least some of their pharmacological properties may result from the combination of different classes of compounds (Pietrovski et al. 2006, Carlini 2003).

Reactive oxygen species (ROS) are generated by normal metabolic processes in all organisms that use oxygen (Frei 1994, Silva et al. 2005, Finkel and Holbrook 2000). However, excessive ROS production can overcome cellular antioxidant defenses and can lead to oxidative stress. Oxidative stress is thought to contribute to the development and progression of several degenerative diseases via DNA mutation, protein oxidation or lipid peroxidation (Finkel and Holbrook 2000, Valko et al. 2004).

Medicinal plants have been traditionally used to treat several human diseases, and their pharmacological and therapeutic properties have been attributed to different chemical constituents isolated from their crude extracts. Of particular importance, chemical constituents with antioxidant activity can be found in plants at high concentrations and are likely to be responsible for their protective effects against various degenerative diseases, including cancer, neurological, and cardiovascular diseases (Evans et al. 2006, Mentreddy 2007, Leite et al. 1986, Velioglu et al. 1998). Thus, plants have many prospective applications in human healthcare because of their antioxidant properties (Silva et al. 2005).
Despite the potential benefits of polyphenols, some products derived from plants can contain toxic compounds. For example, E. tirucalli contains TPA, a dangerous phorbol ester (Lin et al. 2012). Thus, indiscriminate use of crude plant products can have devastating consequences, and these consequences are not always immediately apparent. Injury to a cell's genetic material can cause mutations, cancer, and cell death within a very point in post-exposure period (da Silva et al. 2011). Genotoxic studies have been conducted to evaluate such risks (Kumar et al. 2010). Our main goal in this work was to evaluate the genotoxic and cytotoxic effects of E. tirucalli extract on human leukocytes, the primary barrier of defense for the human immune system.

\section{MATERIALS AND METHODS}

\section{Chemicals}

All chemicals used in this work were of analytical grade. Solvents for the extracts and $L$-Ascorbic acid were purchased from Merck (Darmstadt, Germany). All other reagents were acquired from Sigma Chemical Co. (St. Louis, MO, USA).

\section{PLANT MATERIAL}

The aerial parts of E. tirucalli were harvested in March 2008 at Bagé $\left(31^{\circ} 19^{\prime} 51^{\prime \prime} \mathrm{S} / 54^{\circ} 6^{\prime} 25^{\prime \prime} \mathrm{W}\right)$ (State of Rio Grande do Sul, Brazil). Samples of the collected material were identified by the botanist, Dr. Thais Scott do Canto Dorow, and archived as voucher specimens by register number SMD 10127 in the herbarium of the Department of Biology at Federal University of Santa Maria. Extracts were obtained by adding the fresh aerial parts of E. tirucalli to ethanol (70\%) and storing the mixture at room temperature for seven days with daily agitation. After seven days, the mixture was filtered and the extract was evaporated under reduced pressure to remove the ethanol, which resulted in a crude extract yield of $6.82 \%$. 


\section{DETERMINATION OF TOTAL POLYPHENOLIC CONTENTS}

The total polyphenol concentration in the crude extract was measured spectrophotometrically using a modified Folin-Ciocalteau method (Chandra and Gonzalez de Mejia 2004). Briefly, we added $0.5 \mathrm{~mL}$ of $2 \mathrm{~N}$ Folin-Ciocalteau reagent to $1 \mathrm{~mL}$ of each sample $(0.15 \mathrm{mg} / \mathrm{mL})$ and allowed this mixture to stand for $5 \mathrm{~min}$ before adding $2 \mathrm{~mL}$ of $20 \%$ $\mathrm{Na}_{2} \mathrm{CO}_{3}$. Next we allowed the solution to stand for 10 min before reading it in a Shimadzu-UV-1201 spectrophotometer (Shimadzu, Kyoto, Japan) at $730 \mathrm{~nm}$. We estimated the phenolic compounds in the crude extract in triplicate. Because of the chemical heterogeneity of plant products and the specificity of phenolic reagents, it is very difficult to choose suitable standards for identifying all phenols in a plant extract. Aqueous solutions of gallic acid in the range of $0.001-0.2 \mathrm{mg} / \mathrm{mL}$ as references was used. Thus, it is only possible to get relative equivalents with the standard used. The total polyphenol content was expressed as milligram equivalents of gallic acid per milliliter of the extract.

\section{DETERMINATION OF CONDENSED TANNINS}

Methanolic solutions of rutin in the range of 0.001 $0.2 \mathrm{mg} / \mathrm{mL}$ as references was used. The crude extract was prepared with a standardized procedure of dissolving $0.25 \mathrm{~g}$ in $10 \mathrm{~mL}$ of methanol. The final concentration was $25 \mathrm{mg} / \mathrm{mL}$. The total condensed tannin concentrations in crude extract was measured spectrophotometrically using the modified vanillin method (Morrison et al. 1995). Briefly, we added $0.9 \mathrm{~mL}$ of methanol to $0.1 \mathrm{~mL}$ of each sample $(25 \mathrm{mg} / \mathrm{mL})$. To this mixture, we added $2.5 \mathrm{~mL}$ of Solution $\mathrm{A}(8 \mathrm{~mL}$ of $\mathrm{HCl}$ in 100 $\mathrm{mL}$ of methanol) and $2.5 \mathrm{~mL}$ of Solution $\mathrm{B}(1 \mathrm{~g}$ of vanillin in $100 \mathrm{~mL}$ of methanol). We heated the solution for $10 \mathrm{~min}$ at $60{ }^{\circ} \mathrm{C}$ before reading it in the spectrophotometer at $730 \mathrm{~nm}$. The blank was prepared with $0.1 \mathrm{~mL}$ of water in $0.9 \mathrm{~mL}$ of methanol, $2.5 \mathrm{~mL}$ of Solution A, and $2.5 \mathrm{~mL}$ of Solution B. We determined the condensed tannins in the crude extract in triplicate. The contents were expressed as milligram equivalents of rutin per millilitre of the extracts.

DETERMINATION OF TOTAL FLAVONOIDS

Methanolic solutions of quercetin in the range of $4.0-12.0 \mu \mathrm{g} / \mathrm{mL}$ as references was used. To 2 $\mathrm{mL}$ of each reference solution, we added $20 \mathrm{~mL}$ of methanol and $1 \mathrm{~mL}$ of $5 \%$ methanolic solution of $\mathrm{AlCl}_{3}(\mathrm{w} / \mathrm{v})$ and produced a total volume of $50 \mathrm{~mL}$ with methanol at $20^{\circ} \mathrm{C}$. After $30 \mathrm{~min}$, we measured the absorbance in a Shimadzu-UV-1201 spectrophotometer at $425 \mathrm{~nm}$. We used the same procedure to analyze the crude extract. The blank was $5 \% \mathrm{AlCl}_{3}$ (w/v) (Woisky and Salatino 1998). We estimated the flavonoids in crude extract in triplicate. The contents were expressed as milligram equivalents of quercetin per millilitre of the extracts.

\section{HIGH PERFORMANCE LIQUID CHROMATOGRAPHIY}

Apparatus: The extracts were examined with high performance liquid chromatography (HPLC) using an HPLC system (Shimadzu, Kyoto, Japan), Prominence auto sampler (SIL-20A), which was equipped with Shimadzu LC-20 AT reciprocating pumps connected to a degasser DGU 20A5 with an integrator CBM 20A, a UV-VIS detector DAD (diode) SPD-M20A, and the Software LC solution 1.22 SP1.

Analysis of phenolic compounds: Reverse phase chromatographic analyses were performed under gradient conditions using a C18 column $(4.6 \mathrm{~mm} \times$ $150 \mathrm{~mm}$ ) packed with $5-\mu \mathrm{m}$ diameter particles. The mobile phase was water containing $2 \%$ acetic acid (A) and methanol (B). The composition gradient was $5 \%$ of B to $2 \mathrm{~min}$, when it was changed to obtain $25 \%, 40 \%, 50 \%, 60 \%, 70 \%$, and $100 \% \mathrm{~B}$ at 10 , $20,30,40,50$, and $80 \mathrm{~min}$, respectively, following 
the method described by Laghari and colleagues, with slight modifications (Laghari et al. 2011). The extracts were analyzed at a concentration of $0.150 \mathrm{mg} / \mathrm{mL}$. We investigated the presence of the following six antioxidants: gallic acid, chlorogenic acid, caffeic acid, quercetin, rutin, and kaempferol. These compounds were identified by comparing their retention times and UV absorption spectra with those of the commercial standards. The flow rate was $0.7 \mathrm{~mL} / \mathrm{min}$ and the injection volume was $40 \mu \mathrm{L}$. The wavelengths were $254 \mathrm{~nm}$ for gallic acid; $327 \mathrm{~nm}$ for caffeic and chlorogenic acids; and $365 \mathrm{~nm}$ for quercetin, rutin, and kaempferol. The samples and mobile phase were filtered through a $0.45-\mu \mathrm{m}$ membrane filter (Millipore) and then degassed in an ultrasonic bath before use. Stock solutions of reference standards were prepared in the HPLC mobile phase for quercetin, rutin, and kaempferol at $0.020-0.200 \mathrm{mg} / \mathrm{mL}$ and for gallic, caffeic, and chlorogenic acids at $0.050-0.250 \mathrm{mg} /$ $\mathrm{mL}$. A chromatography peak was confirmed by DAD spectra (200-500 $\mathrm{nm}$ ) and by comparing its retention time with that of a reference standard.

Analysis of 12-O-tetradecanoylphorbol-13acetate (TPA): TPA was identified using a gradient elution HPLC method described by Makkar and colleagues (Makkar et al. 1997). Briefly, samples were injected into a C18 column $(4.6 \mathrm{~mm} \times 250 \mathrm{~mm})$ packed with $5-\mu \mathrm{m}$ diameter particles. The samples initially contained $60 \%$ of solvent A $(1.75 \mathrm{~mL}$ of $85 \% o$-phosphoric acid in $1 \mathrm{~L}$ water) and $40 \%$ of solvent B (acetonitrile), and B was increased to $50 \%$ over $10 \mathrm{~min}, 75 \%$ from 10 to $30 \mathrm{~min}$, and $100 \%$ from 30 to $45 \mathrm{~min}$. The column was then washed with solvent $\mathrm{C}$ ( $2 \%$ tetrahydrofuran in methanol). Detection occurred at $280 \mathrm{~nm}$. Stock solutions of reference standards was prepared in the HPLC mobile phase at $0.020-0.200 \mathrm{mg} / \mathrm{mL}$. A chromatography peak was confirmed by DAD spectra (200-500 $\mathrm{nm}$ ) and by comparing its retention time with that of a reference standard.

\section{HUMAN BLOOD SAMPLES}

Peripheral blood was collected by venipuncture into sterile vials containing 68 I.U. of sodium heparin (BD Vacutainer ${ }^{\circledR}$ ) per $\mathrm{mL}$ of blood. The vials were transferred to the laboratory, and wholeblood cultures were established. The blood samples were stored up to $24 \mathrm{~h}$ at $4{ }^{\circ} \mathrm{C}$ before culturing. This project was approved by the University's Committee of Ethics in Research of Universidade Federal de Santa Maria (RS) (authorization $\mathrm{n}^{\circ}$ 23081.012330/2006-94).

\section{Culture Cell PREPARATION}

The lymphocyte cultures were prepared with whole-blood samples and immediately transferred to $1 \mathrm{~mL}$ of culture medium containing RPMI 1640 supplemented with $10 \%$ fetal bovine serum and $1 \%$ streptomycin/penicillin, as previously described (dos Santos Montagner et al. 2010). The cells were then placed in a microaerophilic environment at 37 ${ }^{\circ} \mathrm{C}$ for $72 \mathrm{~h}$. The solutions under investigation were added with the blood with a $10 \%$ concentration. The solutions analyzed included crude extract of E. tirucalli L. diluted in phosphate-buffered saline (PBS) at concentrations of $0.001 \%, 0.01 \%, 0.1 \%$, $1 \%$, and $10 \%$. TPA, the primary active component in E. tirucalli L., was used as a positive control and at the same concentration found in the plant's phytochemical analysis. Each group consisted of three culture flasks. Genetic and oxidative parameters were analyzed after $72 \mathrm{~h}$ of growth.

\section{ANALYSIS OF OXIDATIVE PARAMETERS}

Lipid peroxidation was quantified by measuring the formation of thiobarbituric acid reactive substances (TBARS) (Ohkawa et al. 1979, dos Santos Montagner et al. 2010). Superoxide dismutase (SOD) (E.C.1.15.1.1) activity was measured spectrophotometrically according to the procedure described by Boveris and Cadenas (1997). The unit of activity was defined as the 
amount of enzyme required to inhibit the rate of epinephrine autoxidation by $50 \%$. Catalase activity (EC 1.11.1.6.) was determined according to the procedures described in a previous report (Aebi 1984). One unit of catalase activity was defined as the activity required to degrade one mol of hydrogen peroxide within $60 \mathrm{~s}$. The protein carbonyl was also quantified according to previously described procedures (Morabito et al. 2004). Total Protein content was determined using the commercially available kit of Wiener Lab. (Rosario, Argentina), kindly donated by the company. The results were expressed in nanomoles of carbonyl groups per mg of protein.

\section{ANALYSIS OF GENOTOXIC PARAMETERS}

To perform the genotoxicity tests, we first counted the total number of leukocytes in a Neubauer chamber (dos Santos Montagner et al. 2010). Viability was assessed by a loss of membrane integrity, which was indicated with trypan blue (Burow et al. 1998). Overall, we counted 300 cells. The genotoxicity test was conducted using comet assay (Singh et al. 1988). Although comet assay is not the only method for measuring oxidative DNA damage, it is one of the most sensitive and accurate and is relatively free of artifacts (Collins 2009). We identified 100 cells in the slides that were submitted for analysis. The cells were visually scored according to tail length, with scores ranging from 0 (no migration) to 4 (maximal migration). Therefore, the damage index for cells ranged from 0 (all cells with no migration) to 400 (all cells with maximal migration). The tests were carried out in triplicate, and the data are presented as mean \pm standard error. The mitotic index and chromosomal instability test were carried out using Cytogenetics Band G. Fifty mitoses were analyzed per sample (Yunis 1976, dos Santos Montagner et al. 2010). In the micronucleus test $(\mathrm{MN})$, the cells were fixed with acetic acid and methanol $(75: 25, \mathrm{v} / \mathrm{v})$, transferred onto clean microscope slides in duplicates, and then stained with 5\% Giemsa. The criteria for scoring cells with MN were described in a previous report (Thomas et al. 2008). One thousand cells were counted for each sample, and the results were expressed as the micronucleus frequency per 1000 cells.

\section{STATISTICAL ANALYSIS}

Statistical software was used to perform all statistical analyses, which included an analysis of variance (ANOVA) followed by a post hoc Bonferroni test. $\mathrm{P}$ values $<0.05$ were considered statistically significant.

\section{RESULTS AND DISCUSSION}

Phenolics are broadly distributed in the plant kingdom and are the most abundant secondary metabolites found in plants (Komali et al. 1999). Flavonoids occur naturally in plant foods and are a common component of our diet. They generally occur as O-glycosides with sugars bound at the $\mathrm{C} 3$ position. Flavonoids have a wide range of biochemical and pharmacological effects, including antioxidant, anti-inflammatory, and antifungal effects (Komali et al. 1999). Analysis of condensed tannins is complicated by the diversity of structures found within this group of compounds. The vanillin method depends on the reaction between vanillin and condensed tannins and the formation of colored complexes (Muchuweti et al. 2006). Tannins have been reported to exert other physiological effects, such as reducing blood pressure, accelerating blood clotting, decreasing serum lipid levels, modulating immune responses, and causing liver necrosis $(\mathrm{Zu}$ et al. 2006). Table I shows the concentrations of these metabolites and some of their constituent compounds, all of which show biological activity. The HPLC-DAD method is most commonly used to identify phenolic compounds (Paganga et al. 1999). Table I also presents the concentrations of seven biologically active compounds. 
TABLE I

Concentrations of analytical markers present in the crude extract of Euphorbia tirucalli $\mathrm{L}$.

\begin{tabular}{lccc}
\hline \multicolumn{1}{c}{ Group / Compound } & $\begin{array}{c}\text { Concentration in the crude } \\
\text { extract }(\boldsymbol{\mu g} / \mathbf{m L})\end{array}$ & Standard Curve $^{\prime}$ & $\mathbf{R}^{\mathbf{2}}$ \\
\hline Polyphenol compounds $^{1}$ & $2072.00 \pm 4.07$ & $\mathrm{y}=34.443 \mathrm{x}-0.0942$ & 0.9937 \\
Condensed tannins $^{1}$ & $689.50 \pm 24.64$ & $\mathrm{y}=0.0423 \mathrm{x}+0.1362$ & 0.9849 \\
Total flavonoids $^{1}$ & $882.00 \pm 41.61$ & $\mathrm{y}=0.0202 \mathrm{x}+0.0031$ & 0.9999 \\
Quercetin $^{2}$ & $1.47 \pm 0.11$ & $\mathrm{y}=32214 \mathrm{x}-259717$ & 0.9968 \\
Rutin $^{2}$ & $0.49 \pm 0.07$ & $\mathrm{y}=19217 \mathrm{x}-16913$ & 0.9998 \\
Gallic acid $^{2}$ & $30.52 \pm 1.19$ & $\mathrm{y}=7606.8 \mathrm{x}-132936$ & 0.9703 \\
Caffeic acid $^{2}$ & $15.61 \pm 3.12$ & $\mathrm{y}=20367 \mathrm{x}-1162400$ & 0.9890 \\
Chlorogenic acid $^{2}$ & $12.37 \pm 2.69$ & $\mathrm{y}=12158 \mathrm{x}+1174.9$ & 0.9996 \\
Kaempferol $^{2}$ & $3.45 \pm 0.11$ & $\mathrm{y}=12647 \mathrm{x}+1178.3$ & 0.9995 \\
${\text { 12-O-tetradecanoylphorbol-13-acetate }(\text { TPA })^{2}}^{2}$ & $3.12 \pm 2.87$ & $\mathrm{y}=27228 \mathrm{x}-31278$ & 0.9971 \\
\hline
\end{tabular}

${ }^{1}$ Determined by spectrophotometric techniques. ${ }^{2}$ Determined by HPLC-DAD. Data are expressed as mean \pm S.D ( $\left.n=3\right)$.

The samples were prepared from the extracts indicated in Table I. Table II shows the final concentrations of these markers produced with the treatments used in this protocol.

Figures 1, 2, and $\mathbf{3}$ demonstrate that treating cultured human leukocytes with varying concentrations of E. tirucalli affected their biological parameters. Regarding the proliferation of leukocytes, the only treatments that caused interference were those with TPA (increase of $50 \pm$ $6.9 \%$ ) and extract at $10 \%$. These treatments showed an increase in proliferation at $17 \% \pm 2.8 \%$. TPA has been described extensively in the literature, which includes reports of proliferative activity (Xu et al. 2015, Shi et al. 2013). The proliferation observed with $10 \%$ extract was consistent with this characteristic, as Table II shows moderate concentrations of 12-O-tetradecanoylphorbol13-acetate. This same effect is also illustrated in Figure 1c. When evaluating the mitotic index, we observed that samples containing higher amounts of TPA had higher rates of cell multiplication, as demonstrated by a cell's increase in mitotic indices. Figure 1b indicates the cell viability means ranged from $0.33 \pm 0.57 \%$ to $6.0 \pm 1.0 \%$. The effects of TPA also were reflected in these samples by increased cell death rates. The phorbol esters can induce inflammatory responses (Wei et al. 2011) and NF$\mathrm{kB}$ expression, which signals a cascade of events leading to apoptosis and a subsequent reduction of leukocytes in culture (Nomura et al. 2000).

TABLE II

Concentrations of bioactive compounds identified in samples according to treatment.

\begin{tabular}{|c|c|c|c|c|c|c|c|}
\hline \multirow[t]{2}{*}{ Compound } & \multicolumn{7}{|c|}{$\begin{array}{c}\text { Concentrations of compounds in each treatment } \\
\text { used in this protocol }(\mu \mathrm{g} / \mathrm{mL})\end{array}$} \\
\hline & PBS (NC) & TPA (PC) & $0.001 \%$ & $0.01 \%$ & $0.1 \%$ & $1 \%$ & $10 \%$ \\
\hline Quercetin & $\mathrm{Nd}$ & $\mathrm{Nd}$ & $\mathrm{Nd}$ & $\mathrm{Nd}$ & $\mathrm{Nd}$ & $\mathrm{Nd}$ & 0.15 \\
\hline Rutin & $\mathrm{Nd}$ & $\mathrm{Nd}$ & $\mathrm{Nd}$ & $\mathrm{Nd}$ & $\mathrm{Nd}$ & $\mathrm{Nd}$ & 0.05 \\
\hline Gallic acid & $\mathrm{Nd}$ & $\mathrm{Nd}$ & $\mathrm{Nd}$ & $\mathrm{Nd}$ & 0.03 & 0.31 & 3.05 \\
\hline Caffeic acid & $\mathrm{Nd}$ & $\mathrm{Nd}$ & $\mathrm{Nd}$ & $\mathrm{Nd}$ & 0.02 & 0.16 & 1.56 \\
\hline Chlorogenic acid & $\mathrm{Nd}$ & $\mathrm{Nd}$ & $\mathrm{Nd}$ & $\mathrm{Nd}$ & $\mathrm{Nd}$ & 0.12 & 1.24 \\
\hline Kaempferol & $\mathrm{Nd}$ & $\mathrm{Nd}$ & $\mathrm{Nd}$ & $\mathrm{Nd}$ & $\mathrm{Nd}$ & 0.03 & 0.35 \\
\hline 12-O-tetradecanoyl phorbol-13-acetate (TPA) & $\mathrm{Nd}$ & 3.12 & $\mathrm{Nd}$ & $\mathrm{Nd}$ & $\mathrm{Nd}$ & 0.03 & 0.31 \\
\hline
\end{tabular}

The data are presented in mean values $(n=3)$, based on the results presented in Table I. Nd: not detectable. 
a
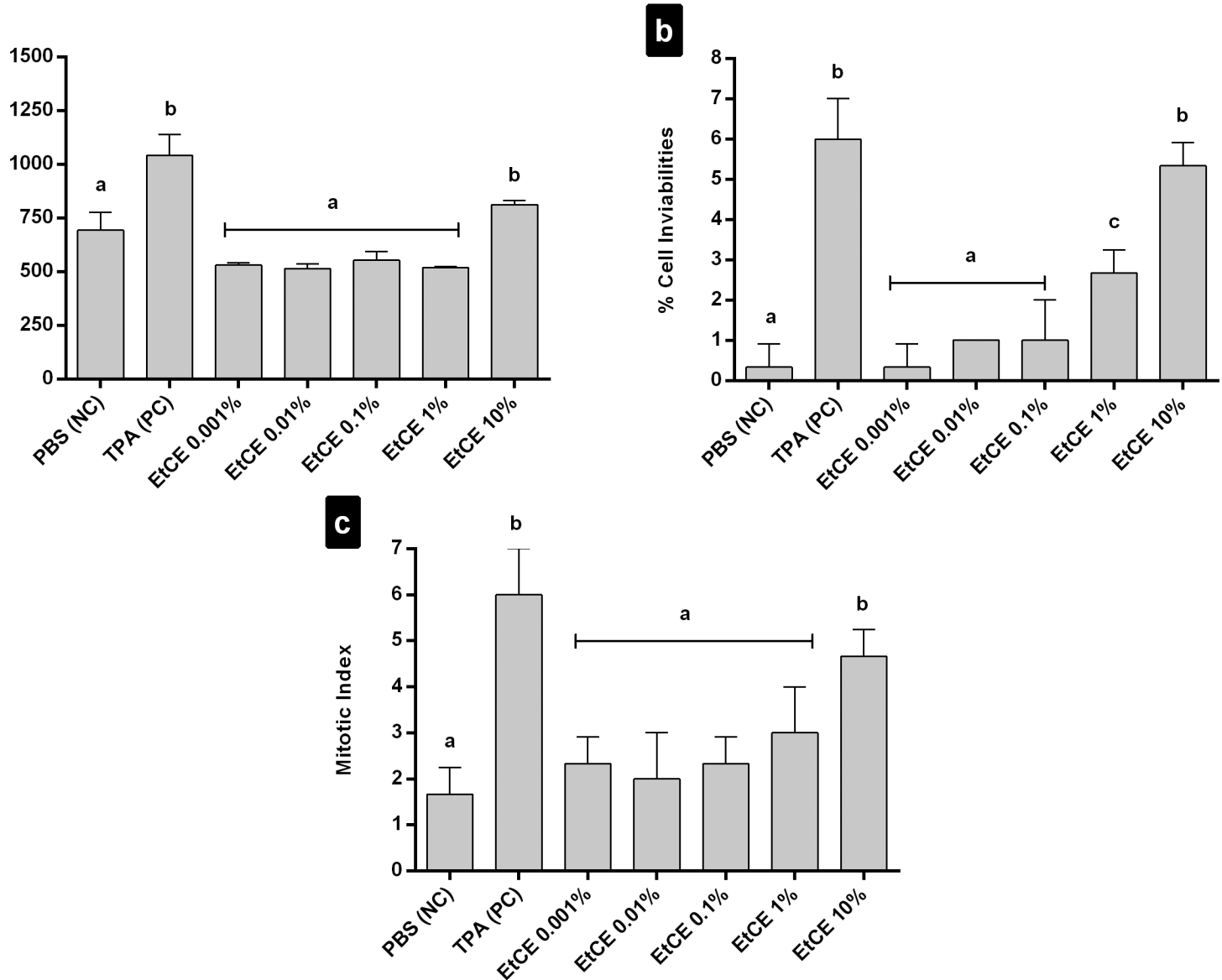

Figure 1 - Markers of cell proliferation. The bar graphs indicate total leukocytes counted (a), percentage of cell inviability (b), and mitotic index (c). PBS: phosphate-buffered saline, TPA: 12-O-tetradecanoylphorbol-13-acetate, EtCE: Euphorbia tirucalli crude extract. Data are presented as mean $\pm \mathrm{SD}(\mathrm{n}=3)$. Letters indicate statistically significant differences.

Figure 2 presents the findings of the oxidative parameter analysis. In Figure $\mathbf{2} \mathbf{a}$ and $\mathbf{b}$, we see the results for two major targets of free radicals, lipids and proteins. Figure $\mathbf{2 c}$ and $\mathbf{2 d}$ describe the activity of two key antioxidant enzymes, SOD and catalase.

The TBARS is a classical model for lipid peroxidation analyses (Ohkawa et al. 1979). Figure 2a reports the levels of lipid peroxidation upon exposure to varying concentrations of E. tirucalli extract. As the figure indicates, the only treatment that increased lipid peroxidation levels was the control TPA $(18.11 \pm 3.73 \%)$. Concentrations of $0.1-10 \%$ showed reduced levels and reached a reduction of $68.9 \pm 3.73 \%$ at the highest concentration. Figure 2b shows that the protein carbonyl content also increased $(107.00 \pm 23.89 \%)$, but only with TPA. Unlike lipid peroxidation, groups with the extract showed no statistically significant changes. In Figure $\mathbf{2 c}$ and $\mathbf{d}$, the antioxidant enzyme activity of SOD and catalase showed no significant changes with any treatment. The compound 12-O-tetradecanoylphorbol-13acetate can induce reactive species production; therefore, we expected an increase in lipid peroxidation and protein carbonylation parameters (Khan et al. 2013). Plant extracts are sources of several potentially beneficial compounds, including the phenolic compounds tested here. These results confirm previous findings that show phenolic compounds, especially flavonoids, participate in oxidative metabolism by directly neutralizing the reactive species (Liu et al. 2008). 

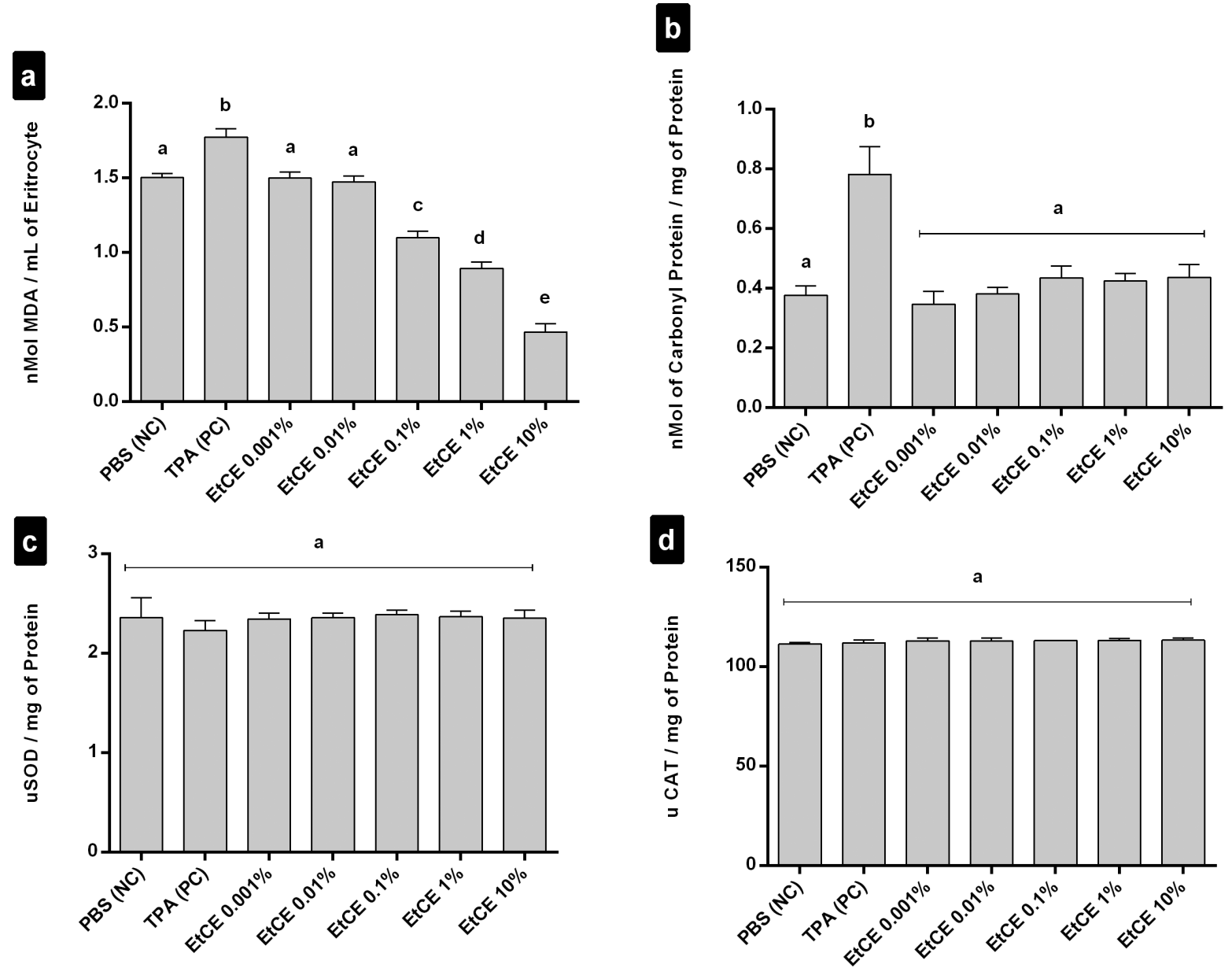

Figure 2 - Markers of oxidative effects. (a) lipid peroxidation, (b) carbonyl protein contents, (c) superoxide dismutase activity, (d) catalase activity. PBS: phosphate-buffered saline, TPA: 12-O-tetradecanoylphorbol-13-acetate, EtCE: Euphorbia tirucalli crude extract. Data are presented as mean $\pm \mathrm{SD}(\mathrm{n}=3)$. Letters indicate statistically significant differences.

Figure 3 illustrates the treatment effects for the genetic evaluation in toxicity. Specifically, Figure 3 illustrates the frequency of micronuclei (a), DNA damage by comet assay (b), and chromosomal abnormalities (c).

A similar pattern is apparent in the test results illustrated in Figure 3a-c. In all cases, TPA was introduced as a genotoxic agent, which subsequently increased the micronuclei (about five times), DNA damage (approximately 40 times), and the number of chromosomal aberrations (about 68 times). Such effects are widely reported and well characterized in previous studies (Okabe et al. 2011, Kumar et al. 2012, Kawabe et al. 2013).
Measurements of the micronucleus frequency in cultured human lymphocytes were used to evaluate chromosomal damage following exposure to genotoxic agents (Nefic and Handzic 2013). We observed an increased frequency of micronuclei, thus indicating a genotoxic risk at $1 \%$ and $10 \%$ concentrations of crude extract, with increases ranging from three to five times that of the negative control (PBS). The same observations were made when the frequency of chromosomal aberrations was evaluated by determining the numerical and structural chromosomal abnormalities. The analysis also indicated a genotoxic risk with concentrations of $1 \%$ and $10 \%$, with chromosome damage 

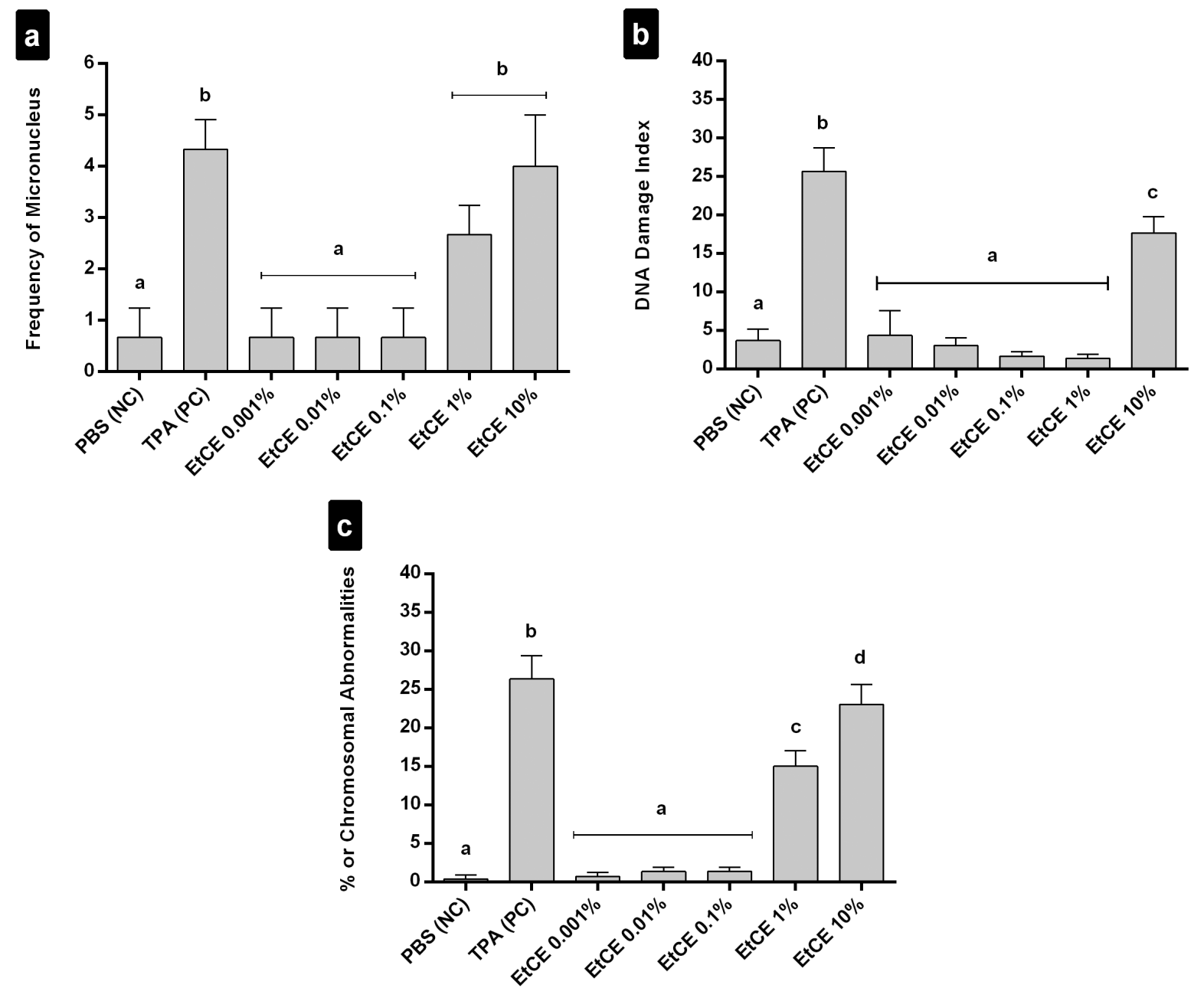

Figure 3 - Markers of genotoxic effects. Markers were the frequency of micronuclei (a), DNA damage by comet assay (b), and chromosomal abnormalities (c). PBS: Phosphate-buffered saline, TPA: 12-O-tetradecanoylphorbol-13-acetate, EtCE: Euphorbia tirucalli crude extract. Data are presented as mean $\pm \mathrm{SD}(\mathrm{n}=3)$. The letters indicate statistically significant differences.

increasing from 44 to 68 times, respectively. The comet assay, also called the single cell electrophoresis assay, can determine DNA strand breaks after in vitro exposures. The comet assay involves electrophoresis of lysed cells embedded in agarose on a microscope slide. Undamaged DNA remains within the core, whereas fragmented DNA migrates from the core toward the anode, forming an image that resembles a comet with a head and tail (Lee et al. 2013). We identified genotoxic damage only in cultures containing the crude extract at $10 \%$, indicating an increase in DNA breakage that was 38 times higher than that for the negative control resembling the treatment with TPA. As Table II indicates, we found that extract samples at $1 \%$ and $10 \%$ contained higher contents of active compounds, which included polyphenols, phorbol ester, and TPA. Our findings demonstrate that these extracts have high genotoxic potential. Polyphenols have been extensively reported as having antigenotoxic activity and highly protective effects for genetic material (Zheng et al. 2010, Rajavelu et al. 2011, Katiyar 2011, Pedret et al. 2012). On the other hand, TPA is a genotoxic agent (Okabe et al. 2011, Kumar et al. 2012, Kawabe et al. 2013). We therefore conclude that the 
present findings reflect TPA's effects on the plant composition, and therefore, the extract used in the tests.

Even though this plant is popularly used to treat various diseases, it is potentially a genotoxic agent, especially in the presence of phorbol ester. Its indiscriminate use can actually promote tumors and confer large genetic risks to its users.

\section{ACKNOWLEDGMENTS}

The authors are grateful to Conselho Nacional de Desenvolvimento Científico e Tecnológico (CNPq) and Fundação de Amparo à Pesquisa do Estado do Rio Grande do Sul (FAPERGS) for financial support, to Wiener Lab Group for the donation of kits for laboratory measurements and to professor Dr. Thais Scott do Canto Dorow for the botanical identification of the plant material used in this paper.

\section{RESUMO}

Euphorbia tirucalli (L.), comumente conhecida como aveloz, tem sido indiscriminadamente usada na medicina popular para o tratamento de várias doenças. Entretanto, alguns componentes podem ter consequências devastadoras. A lesão do material genético da célula pode causar mutações, câncer e morte celular. Nosso principal objetivo neste trabalho foi avaliar os efeitos genotóxicos e citotóxicos do extrato de E. tirucalli em leucócitos humanos. Para este propósito, realizamos uma análise fitoquímica dos componentes da planta. Em uma segunda etapa, culturas de leucócitos humanos foram tratados com diferentes concentrações do extrato seco da planta e então avaliamos os perfis oxidativos e genotóxicos nestes leucócitos. Nossos resultados mostraram que nas concentrações de $1 \%$ e $10 \%$, o extrato de aveloz atua como agente genotóxico, o qual pode danificar o DNA e aumentar a dano oxidativo. Concluímos que, apesar do uso popular, a aveloz pode atuar como agente genotóxico, especialmente por conter o éster de forbol. O uso indiscriminado da aveloz pode na verdade promover tumores e, portanto, carrega um risco genético considerável para seus usuários.
Palavras-chave: Aveloz, Euphorbia tirucalli, leucócitos, genotóxico, citotóxico.

\section{REFERENCES}

AEBI H. 1984. Catalase in vitro. Methods Enzymol 105: 121126.

AGRA MDF, FREITAS PFD AND BARBOSA-FILHO JM. 2007. Synopsis of the plants known as medicinal and poisonous in Northeast of Brazil. Rev Bras Farmacogn 17: 114-140.

BIAVATTI MW, MARENSI V, LEITE SN AND REIS A. 2007. Ethnopharmacognostic survey on botanical compendia for potential cosmeceutic species from Atlantic Forest. Rev Bras Farmacogn 17: 640-653.

BOVERIS A AND CADENAS E. 1997. Cellular sources and steady-state levels of reactive oxygen species. Lung Biology in Health and Disease 105: 1-26.

BUROW ME, WELDON CB, TANG Y, NAVAR GL, KRAJEWSKI S, REED JC, HAMMOND TG, CLEJAN S AND BECKMAN BS. 1998. Differences in susceptibility to tumor necrosis factor $\alpha$-induced apoptosis among MCF-7 breast cancer cell variants. Cancer Res 58: 4940-4946.

CARLINI E. 2003. Plants and the central nervous system. Pharmacol Biochem Be 75: 501-512.

CHANDRA S AND GONZALEZ DE MEJIA E. 2004. Polyphenolic compounds, antioxidant capacity, and quinone reductase activity of an aqueous extract of Ardisia compressa in comparison to mate (Ilex paraguariensis) and green (Camellia sinensis) teas. J Agr Food Chem 52: 3583-3589.

COLLINS AR. 2009. Investigating oxidative DNA damage and its repair using the comet assay. Mutat Res-Rev Mutat 681: 24-32.

DA SILVA RMDR, TEIXEIRA DF, SAMPAIO ALF AND DE AGUIAR LEITÃo TC. 2011. Analysis of in vitro activity of high dilutions of Euphorbia tirucalli L. in human melanoma cells. In J High Dilution Res 10.

Dos SANTOS MONTAGNER GFF, SAGRILlO M, MACHADO MM, ALMEIDA RC, MOSTARDEIRO CP, DUARTE MMMF AND DA CRUZ IBM. 2010. Toxicological effects of ultraviolet radiation on lymphocyte cells with different manganese superoxide dismutase Ala16Val polymorphism genotypes. Toxicol in Vitro 24: 1410-1416.

EVANS DA, HIRSCH JB AND DUSHENKOV S. 2006. Phenolics, inflammation and nutrigenomics. J Sci Food Agr 86: 25032509.

FINKEL T AND HOLBROOK NJ. 2000. Oxidants, oxidative stress and the biology of ageing. Nature 408: 239-247.

FREI B. 1994. Reactive oxygen species and antioxidant vitamins: mechanisms of action. Am I Med 97: S5-S13.

FÜRSTENBERGER G AND HECKER E. 1986. On the active principles of the Euphorbiaceae, XII. Highly unsaturated irritant diterpene esters from Euphorbia tirucalli originating from Madagascar. J Nat Prod 49: 386-397. 
Jurberg P, CABral Neto JB AND Schall VT. 1985. Molluscicide activity of the" Avelós" plant (Euphorbia tirucalli, L.) on Biomphalaria glabrata, the mollusc vector of schistosomiasis. Mem Inst Oswaldo Cruz 80: 423-427.

KATIYAR SK. 2011. Green tea prevents non-melanoma skin cancer by enhancing DNA repair. Arch Biochem Biophys 508: 152-158.

KaWABE M, Urano K, SUGURO M, NumANO T, TAGUChi F, TSUTSUMI H AND FURUKAWA F. 2013. Tumor Promotion by $12-\mathrm{O}-$ Tetradecanoylphorbol-13-Acetate in an UltraShort-Term Skin Carcinogenesis Bioassay Using rasH2 Mice. Vet Pathol 50: 903-908.

KHAN AQ, KHAN R, QAMAR W, LATEEF A, REHMAN MU, TAHIR M, ALI F, HAMIZA OO, HASAN SK AND SULTANA S. 2013. Geraniol attenuates 12-O-tetradecanoylphorbol13-acetate (TPA)-induced oxidative stress and inflammation in mouse skin: Possible role of p38 MAP Kinase and NF- $\kappa$ B. Exp Mol Pathol 94: 419-429.

KOMALI AS, ZHENG Z AND SHETTY K. 1999. A mathematical model for the growth kinetics and synthesis of phenolics in oregano (Origanum vulgare) shoot cultures inoculated with Pseudomonas species. Process Biochem 35: 227-235.

Kumar A, Prasad M, Mishra D, SRIVASTAV SK AND SRIVASTAV AK. 2010. Toxicity of aqueous extract of Euphorbia tirucalli latex on catfish, Heteropneustes fossilis. Ecotox Environ Safe 73: 1671-1673.

Kumar G, DAnge P, Kailaje V, VAidya MM, RAMCHANDANI AG AND MARU GB. 2012. Polymeric black tea polyphenols modulate the localization and activity of 12-O-tetradecanoylphorbol-13-acetatemediated kinases in mouse skin: Mechanisms of their anti-tumor-promoting action. Free Radical Bio Med 53: 1358-1370.

LAGHARI AH, MEMON S, Nelofar A, KHAN KM AND YASMIN A. 2011. Determination of free phenolic acids and antioxidant activity of methanolic extracts obtained from fruits and leaves of Chenopodium album. Food Chem 126: 1850-1855.

LEE RF, BULSKI K, ADAMS JD, PEDEN-ADAMS M, BOSSART GD, KING L AND FAIR PA. 2013. DNA strand breaks (comet assay) in blood lymphocytes from wild bottlenose dolphins. Mar Pollut Bull 77: 355-360.

LeITE J, De Lourdes V, SEABra M, MALuf E, Assolant K, Suchecki D, Tufik S, Klepacz S, CAlil HM AND CARLINI E. 1986. Pharmacology of lemongrass (Cymbopogon citratus Stapf). III. Assessment of eventual toxic, hypnotic and anxiolytic effects on humans. J Ethnopharmacology 17: 75-83.

LIN M-W, LIN A-S, WU D-C, WANG SS, CHANG F-R, WU Y-C AND HUANG Y-B. 2012. Euphol from Euphorbia tirucalli selectively inhibits human gastric cancer cell growth through the induction of ERK1/2-mediated apoptosis. Food Chem Toxicol 50: 4333-4339.
LIU X, CUI C, ZHAO M, WANG J, LUO W, YANG B AND JIANG Y. 2008. Identification of phenolics in the fruit of emblica (Phyllanthus emblica L.) and their antioxidant activities. Food Chem 109: 909-915.

MADUREIRA AM, FERREIRA M-JU, GYEMANT N, UGOCSAI $\mathrm{K}$, ASCENSO JR, ABREU PM, HOHMANN J AND MOLNAR J. 2004. Rearranged jatrophane-type diterpenes from Euphorbia species. Evaluation of their effects on the reversal of multidrug resistance. Planta Med 70: 45-49.

MAKKAR H, BECKER K, SPORER F AND WINK M. 1997. Studies on nutritive potential and toxic constituents of different provenances of Jatropha curcas. J Agr Food Chem 45: 3152-3157.

MENDONÇA FILHO R AND MENEZES F. 2003. Estudo da utilização de plantas medicinais pela população da Ilha Grande-RJ. Rev Bras Farmacogn 13: 55-58.

MENGUE S, MENTZ L AND SCHENKEL E. 2001. Uso de plantas medicinais na gravidez. Rev Bras Farmacogn 11: 21-35.

MENTREDDY SR. 2007. Medicinal plant species with potential antidiabetic properties. J Sci Food Agr 87: 743-750.

Morabito F, Cristani M, Saija A, Stelitano C, Callea V, TOMAino A, Minciullo P AND GANGEMI S. 2004. Lipid peroxidation and protein oxidation in patients affected by Hodgkin's lymphoma. Mediators Inflamm 13: 381-383.

Morrison I, Asiedu E, Stuchbury T AND Powell A. 1995. Determination of lignin and tannin contents of cowpea seed coats. Annals of Botany 76: 287-290.

Muchuweti M, NDHLALA A AND KasiamHuru A. 2006. Analysis of phenolic compounds including tannins, gallotannins and flavanols of Uapaca kirkiana fruit. Food Chem 94: 415-419.

NEFIC H AND HANDZIC I. 2013. The effect of age, sex, and lifestyle factors on micronucleus frequency in peripheral blood lymphocytes of the Bosnian population. Mutat ResGen Tox En 753: 1-11.

NOMURA M, MA W-Y, CHEN N, BODE AM AND DONG Z. 2000. Inhibition of 12-O-tetradecanoylphorbol-13acetate-induced NF- $\kappa \mathrm{B}$ activation by tea polyphenols,(-)epigallocatechin gallate and theaflavins. Carcinogenesis 21: 1885-1890.

OHKAWA H, OHISHI N AND YAGI K. 1979. Assay for lipid peroxides in animal tissues by thiobarbituric acid reaction. Anal Biochem 95: 351-358.

OKABE K, KATO K, TERANISHI M, OKUMURA M, FUKUI R, MORI T, FUKUSHIMA N AND TSUJIUCHI T. 2011. Induction of lysophosphatidic acid receptor-3 by 12-O-tetradecanoylphorbol-13-acetate stimulates cell migration of rat liver cells. Cancer letters 309: 236-242.

Paganga G, Miller N And Rice-Evans CA. 1999. The polyphenolic content of fruit and vegetables and their antioxidant activities. What does a serving constitute? Free Radical Res 30: 153-162. 
PEDret A, VAlls RM, FERnÁNDEZ-CASTILleJo S, CATALÁN Ú, ROMEU M, GIRALT M, LAMUELA-RAVENTÓS RM, MEDINA-REMÓN A, ARIJA V AND ARANDA N. 2012. Polyphenol-rich foods exhibit DNA antioxidative properties and protect the glutathione system in healthy subjects. Mol Nutr Food Res 56: 1025-1033.

Pereira R, Oliveira M AND Lemos G. 2004. Plantas utilizadas como medicinais no município de Campos de Goytacazes-RJ. Rev Bras Farmacogn 14: 37-40.

PIETROVSKI EF, RosA KA, FACUNDO VA, RIOS K, MARQUES MCA AND SANTOS AR. 2006. Antinociceptive properties of the ethanolic extract and of the triterpene $3 \beta, 6 \beta$, $16 \beta$-trihidroxilup-20 (29)-ene obtained from the flowers of Combretum leprosum in mice. Pharmacol Biochem Be 83: 90-99.

RAJAVELU A, TULYASHEVA Z, JAISWAL R, JELTSCH A AND KUHNERT N. 2011. The inhibition of the mammalian DNA methyltransferase 3a (Dnmt3a) by dietary black tea and coffee polyphenols. BMC biochemistry 12: 16 .

RitTer M, SOBIERAJSKI G, SCHENKEL E AND MENTZ L. 2002. Plantas usadas como medicinais no município de Ipê, RS, Brasil. Rev Bras Farmacogn 12: 51-62.

SHI M-D, SHIH Y-W, LEE Y-S, CHENG Y-F AND TSAI L-Y. 2013. Suppression of 12-O-Tetradecanoylphorbol-13Acetate-Induced MCF-7 Breast Adenocarcinoma Cells Invasion/Migration by $\alpha$-Tomatine Through Activating

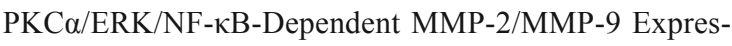
sions. Cell Biochem Biophys 66: 161-174.

Silva CD, Herdeiro R, Mathias C, PANeK A, Silveira C, Rodrigues V, RENNÓ M, FALCÃo D, CERQUEIRA D AND MINTO A. 2005. Evaluation of antioxidant activity of Brazilian plants. Pharmacol Res 52: 229-233.

SINGH NP, MCCOY MT, TICE RR AND SCHNEIDER EL. 1988. A simple technique for quantitation of low levels of DNA damage in individual cells. Exp Cell Res 175: 184-191.

THOMAS P, HARVEY S, GRUNER T AND FENECH M. 2008. The buccal cytome and micronucleus frequency is substantially altered in Down's syndrome and normal ageing compared to young healthy controls. Mut Res-Fund Mol M 638: 37-47.

VALADARES MC, CARRUCHA SG, ACCORSI W AND QUEIROZ ML. 2006. Euphorbia tirucalli L. modulates myelopoiesis and enhances the resistance of tumour-bearing mice. Int Immunol 6: 294-299.

VALKO M, IZAKOVIC M, MAZUR M, RHODES CJ AND TELSER J. 2004. Role of oxygen radicals in DNA damage and cancer incidence. Mol Cell Biochem 266: 37-56.

Velioglu Y, MAZZA G, GAO L AND OOMAH B. 1998. Antioxidant activity and total phenolics in selected fruits, vegetables, and grain products. J Agr Food Chem 46: 4113-4117.

VENDRUSCOLO GS, RATES SMK AND MENTZ LA. 2005. Dados químicos e farmacológicos sobre as plantas utilizadas como medicinais pela comunidade do bairro Ponta Grossa, Porto Alegre, Rio Grande do Sul. Rev Bras Farmacogn 15: 361-372.

WEI W-C, LIN S-Y, CHEN Y-J, WEN C-C, HUANG C-Y, PALANISAMY A, YANG N-S AND SHEU J-H. 2011. Topical application of marine briarane-type diterpenes effectively inhibits 12-O-tetradecanoylphorbol-13-acetate-induced inflammation and dermatitis in murine skin. J Biomed Sci 18: 1-13.

WOISKY RG AND SALATINO A. 1998. Analysis of propolis: Some parameters and procedures for chemical quality control. J Apicult Res 37: 99-105.

Xu X, PROUGH RA AND SAmuelson DJ. 2015. Differential 12-O-Tetradecanoylphorbol-13-acetate-induced activation of rat mammary carcinoma susceptibility Fbxo10 variant promoters via a PKC-AP1 pathway. Mol Carcinogen 54(2): 134-147.

YADAV R, SRIVASTAVA V, CHANDRA R AND SINGH A. 2002. Larvicidal activity of latex and stem bark of Euphorbia tirucalli plant on the mosquito Culex quinquefasciatus. J Commun Dis 34: 264-269.

YUNIS JJ. 1976. High resolution of human chromosomes. Science 191: 1268-1270.

ZHENG R, SHI Y, JiA Z, ZHAO C, ZHANG Q AND TAN X. 2010. Fast repair of DNA radicals. Chem Soc Rev 39: 2827-2834.

ZU Y, LI C, FU Y AND ZHAO C. 2006. Simultaneous determination of catechin, rutin, quercetin kaempferol and isorhamnetin in the extract of sea buckthorn (Hippophae rhamnoides L.) leaves by RP-HPLC with DAD. J Pharm Biomed Anal 41: 714-719. 